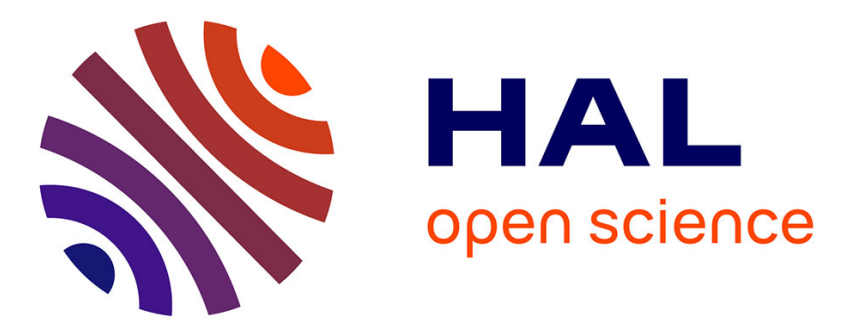

\title{
Relations between International Consultants and the Local Engineering Force in Urban Infrastructures
}

\author{
Eric Baye, Jean-Michel Cusset, Nguyen Thien Phu
}

\section{To cite this version:}

Eric Baye, Jean-Michel Cusset, Nguyen Thien Phu. Relations between International Consultants and the Local Engineering Force in Urban Infrastructures. Gubry Patrick; Castiglioni Franck; Cusset Jean-Michel; Nguyen Thi Thieng; Pham Thuy Huong. The vietnamese city in transition, ISEAS; IMV; PADDI, pp.239-269, 2010, 978-981-230-825-2. halshs-01492718

\section{HAL Id: halshs-01492718 https://shs.hal.science/halshs-01492718}

Submitted on 20 Mar 2017

HAL is a multi-disciplinary open access archive for the deposit and dissemination of scientific research documents, whether they are published or not. The documents may come from teaching and research institutions in France or abroad, or from public or private research centers.
L'archive ouverte pluridisciplinaire HAL, est destinée au dépôt et à la diffusion de documents scientifiques de niveau recherche, publiés ou non, émanant des établissements d'enseignement et de recherche français ou étrangers, des laboratoires publics ou privés. 


\title{
8
}

\section{Relations between International Consultants and the Local Engineering Force in Urban Infrastructures}

\author{
Eric Baye
}

Jean-Michel Cusset

in collaboration with Nguyen Thien Phu

Little research has been carried out on consultancy firms and consultants working in the field of infrastructure and urban technical services in Asia, with the notable exception of Rimmer and Dick's contribution on urban transport in South-East Asia and our own work on the subject (Baye and Cusset 1990; Baye and Lorrain 1997). In the past decade, the context of intervention has become increasingly complex for consultants, for several reasons: the diversification of options associated with a project, whether technological, financial (that is, urban transport infrastructure concession, BOT or "Build-Operate-Transfer", etc.) or institutional (project management strengthening, establishment of autonomous municipal enterprises, etc.); increased awareness of environmental impacts; the need for consultants to be able to work with representatives of the residents or users (participative 
and consultative methods, educating the public regarding public service pricing). In conjunction with this new configuration, the development of information technology in its widest sense has opened up new possibilities for the modelling, simulation and representation of phenomena (for example, satellite images, databases) by making new or previously unaffordable tools available to small professional engineering firms.

The increased complexity of applied methods might not always have resulted in increased efficiency. However, within a few decades, consultants' professional practice has been altered in such a way that they now occupy an important position within decision-making and innovation processes.

Two concepts are commonly used to describe the role of consultants in the development process. The first describes them as laying the groundwork for exporting equipment; the second concept is more insightful and portrays consultants as a driving force for the development of "models"1 in countries receiving international aid. Rather than following either of these two concepts, our research - based on cases in Hanoi, Ho Chi Minh City and Phnom Penh - consisted in identifying which foreign consultancy firms were involved in urban infrastructure projects. Our aim was to observe their approach, their relation with project management and the way they were cooperating with the local engineering force, especially in terms of their influence on decision-making. The objective was simple: re-examine the issues surrounding the role of consultants in the urban development process. Our research was not actually restricted to the two Vietnamese metropolises.

Although they obviously do not represent international experts as a whole, our investigations have focused almost exclusively on consultancy firms and engineering firms. We restricted ourselves to planning, specific studies and the implementation of equipment associated with the following areas: transport and public roads, traffic regulation, urban water cycle and solid waste management cycle (mainly household waste). We nevertheless made use of opportunities to glimpse into other sectors, such as port and airport infrastructure, as they also contribute to the evolution of urban forms.

This chapter should be read as a synthesis of the main results rather than as an analysis. We will begin with an account of the presence of foreign and Vietnamese consultancy firms in the urban field, then attempts to outline the major elements surfacing from the confluence of international consultants' and local stakeholders' viewpoints. Since this book does not cover Cambodia, the specific situation in Phnom Penh will only be briefly mentioned for the sake of comparison. Finally, we will suggest some directions for further research. 
Our method was based on the following four approaches:

- A survey of academic literature on the subject;

- General interviews with about thirty heads of cooperation agencies, donors and administration, conducted in France, Vietnam and Cambodia, as well as in Manila (Asian Development Bank);

- In-depth interviews: about thirty with international and Vietnamese consultants in Hanoi, Ho Chi Minh City and Phnom Penh, to improve our understanding of the organisations involved on the ground and learn from their experience; twenty-seven interviews with high ranking Vietnamese officials from central administration and People's Committees, aiming to record the experiences of "project management";

- Ongoing internet research in order to get a clearer picture of the profile of consultancy firms and of the projects they were involved in.

Finally, we set up an embryonic database containing international consultants' interventions in projects to flesh out our analyses with relatively precise information which, to our knowledge, had never so far been gathered.

\section{Foreign Expertise in Vietnam}

Foreign consultancy firms only really started to get involved in Vietnam at the beginning of the 1990s. Their interventions have largely been laid out by multilateral and bilateral aid initiatives, which traditionally allow for foreign consultants wages and - at least in theory - for a transfer of know-how.

\section{Nationalities of the Consultancy Firms}

We inventoried a total of ninety-three consultancy firms their distribution per nationality is illustrated below (Figure 8.1). It corresponds quite closely to levels of bilateral aid to Vietnam, at least in the case of France, Finland, Denmark, Australia and, of course, Japan.

Large organisations clearly predominate among Westerners (groups of over one thousand people), either directly (for example, Systra, Jaakko Pöyry, Louis Berger, GHD, Maunsell, etc.) or through their subsidiaries, which themselves are often of considerable size (for example, MVA, Soil and Water, Elektrowatt, etc). As an emerging market, Vietnam is probably the target of gradual manoeuvres - the pace of which is determined at the initiative of financial backers - from major international engineering 
FIGURE 8.1

International Consultants in Vietnam: Distribution by Nationality

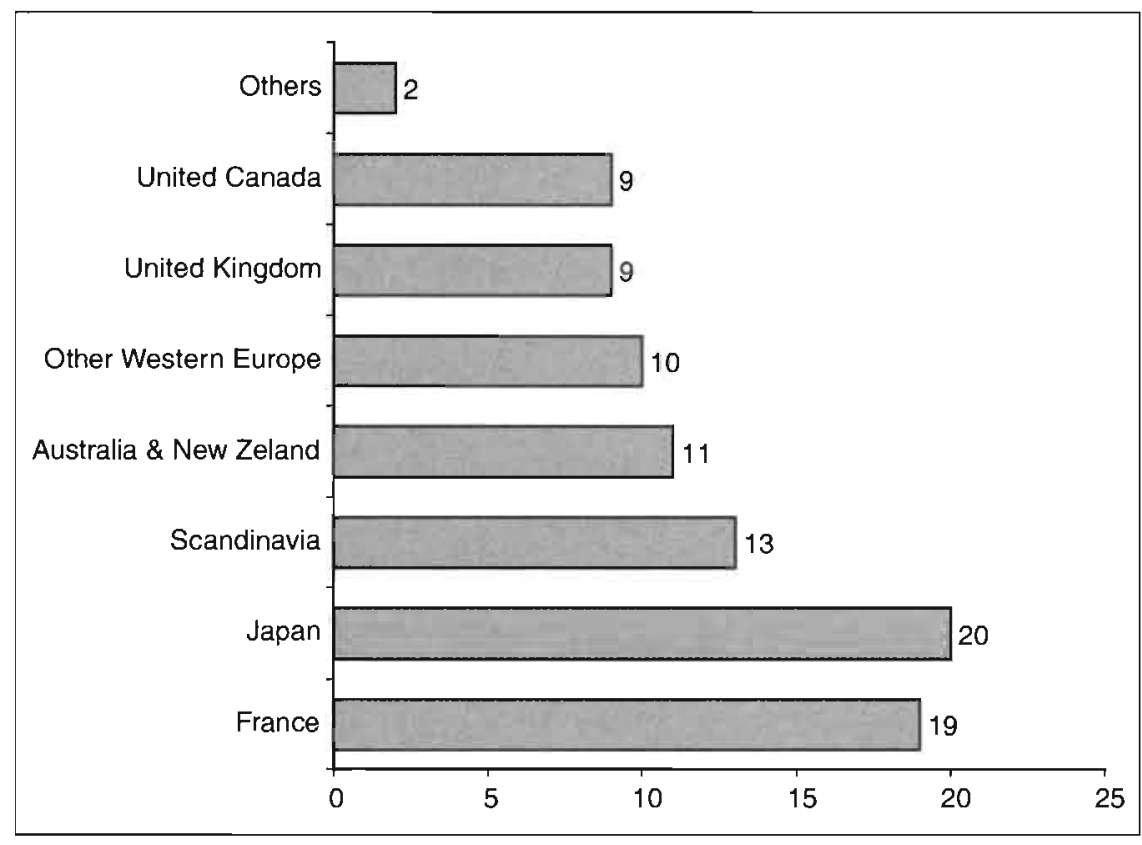

* Other Western Europe (France and United Kingdom excluded). Source: Database of the authors.

firms interested not only in its cities, but who are also in staking out the country's overall infrastructure and energy projects. For these firms, the economic heart of the work lies in detailed studies and project supervision (or engineering project management) far more than in planning.

The local offices of these groups or their subsidiaries act as observation posts enabling them to keep track of the evolution of large-scale urban projects and interpret market signals.

Small Western consultancy firms (under fifty employees) are plentiful, but often intervene on a one-off basis, or else provide support for larger organisations with strong enough references and foundations to be working on international projects.

The Japanese are the most powerful as their market is sanction by JCA's and - to a lesser extent - JBIC' ${ }^{2}$ cooperation system. Japanese engineering firms which have the strongest presence in the area of urban infrastructure are generally multisectoral (for example, Nippon Koei, Pacific Consultants 
International, NJS Consultants Co. Ltd, Almec) and, on average, smaller than their large Western competitors (generally between 500 and 1,500 employees). However, there are few "small" Japanese consultancy firms.

In brief, having observed the consultancy market, we can distinguish four categories of engineering firms:

- Those with short-term views on Vietnam who have had access to a non-renewable opportunity such as bilateral funds.

- Companies not specifically established in the urban services market but otherwise committed to a polysectoral strategy of penetration of the Vietnamese market as a whole.

- Companies solidly and sustainably positioned in one or several sectors of the urban market, and which also often have a strong presence in other sectors. There is a strong Japanese presence in this category.

- More specialised, mid-sized companies, which make a name for themselves in Vietnam by getting involved in the preparation and planning of projects. Among others, we will mention Soil and Water, Burgeap, Safege and the international group MVA.

\section{Sites and Sectors of Intervention}

Foreign interventions in urban engineering have grown in parallel with related infrastructure projects and international aid. A total of 206 missions, either underway or completed, were inventoried in Vietnam, of which 96 were in Hanoi and Ho Chi Minh City, 80 in other cities, and 24 were interventions on a national scale which included urban aspects. Among provincial cities (excluding Ho Chi Minh City), Haiphong is clearly the main beneficiary with 15 projects, followed by Hue (8) and Danang (6).

The number of interventions by nationality emphasises the prominence of countries with the greatest number of consultancy firms. The French carried out 31 per cent of total interventions over a period of almost ten years and the Japanese 26 per cent (Figure 8.2). Australians only represent 7 per cent of the total, and Anglo-Saxons as a whole 22 per cent. However, the analysis of interventions since 2000 shows that the situation is not that favourable for French professional engineering firms, especially in their traditional areas of excellence, water and sanitation, partly due to the dynamism of FINIDA, DANIDA and AUSaid ${ }^{3}$ programmes. The near absence of Asian countries can be explained by their low levels of bilateral aid to Vietnam as well as by the fact that their consultancy firms' lack the adequate references needed to be selected by multilateral institutions. However, some are involved in development operations (especially Koreans in Hanoi). 
FIGURE 8.2

\section{Distribution of Interventions in Vietnam by Nationality of Consultancy Firms}

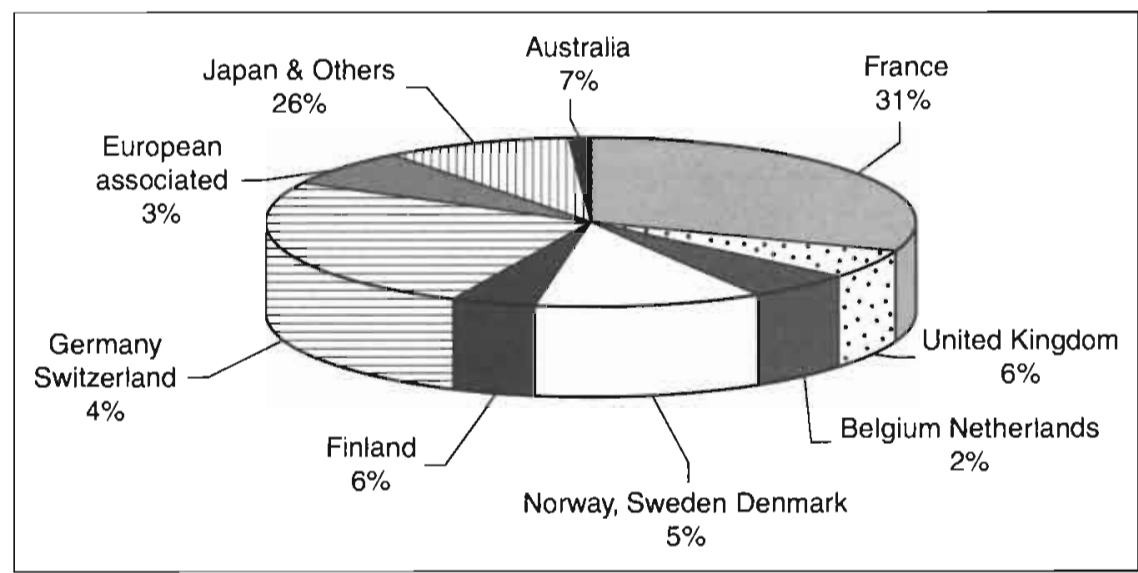

Source: Database of the authors.

Distribution by area of intervention by and large reflects the priorities defined by Vietnamese authorities in relation to the main donors (Figure 8.3).

Missions concerning the urban water cycle predominate with over 43 per cent of total foreign interventions, due mainly to the development of projects in provincial cities such as Nam Dinh, Hue, Haiphong and Dong Nai, with a high propensity for combining water, sanitation and sometimes waste. Although there is a far greater number of foreign interventions in Ho Chi Minh City, where Japanese intervention is privileged, the distribution of foreign intervention by sector in both Hanoi and Ho Chi Minh City is comparable to the rest of the country in the areas of transport, waste, sanitation and environment. At this stage of our investigation, it is still not clear whether this is a coincidence or the indirect result of Vietnamese authorities' determination to develop projects at a matching pace in both metropolises. Water is an exception to this rule: the number of foreign consultant missions in Hanoi (21.4 per cent) is almost double that in Ho Chi Minh City (11.1 per cent), which could be explained by the fact that the capital's network and equipment are in a more critical state.

The geographical distribution of interventions by sector shows a noticeable difference between Hanoi and Ho Chi Minh City, as well as between both metropolises and other cities. Water and sanitation constitute over 50 per 
FIGURE 8.3

\section{Distribution of Interventions by Sector over the Whole Country}

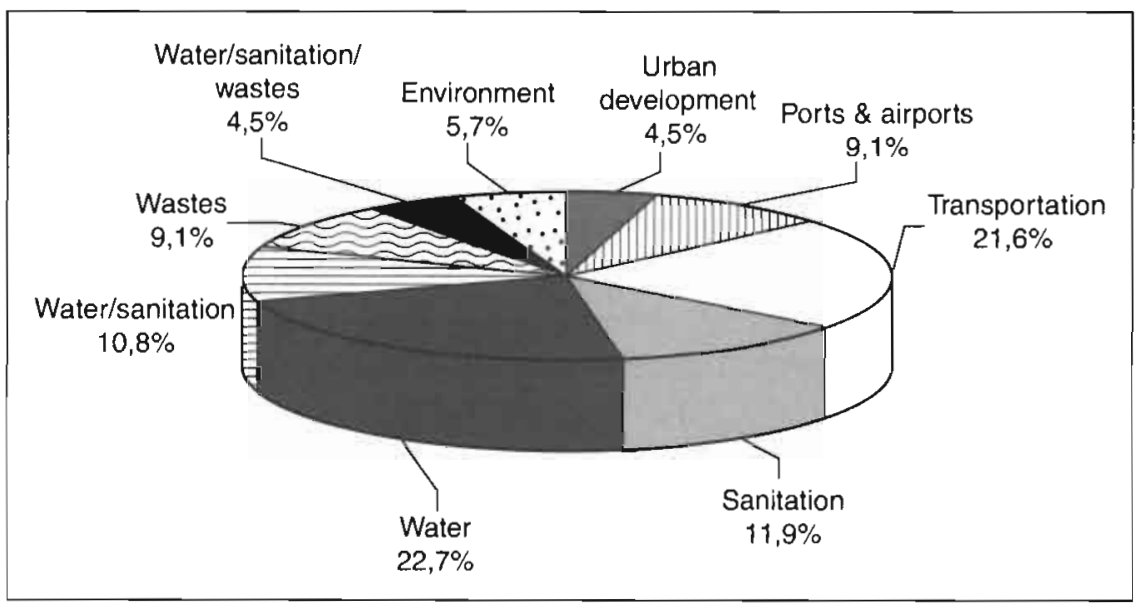

Source: Database of the authors.

cent of the total projects in provincial cities, whereas transport occupies a very low position ( 2.5 per cent). By contrast, urban transports are the first sector of intervention in Hanoi (40.5 per cent) and Ho Chi Minh City (35.2 per cent) (Figures 8.4 and 8.5).

FIGURE 8.4

Distribution of Interventions by Sector in Hanoi



Source: Database of the authors. 
FIGURE 8.5

Distribution of Interventions by Sector in Ho Chi Minh City

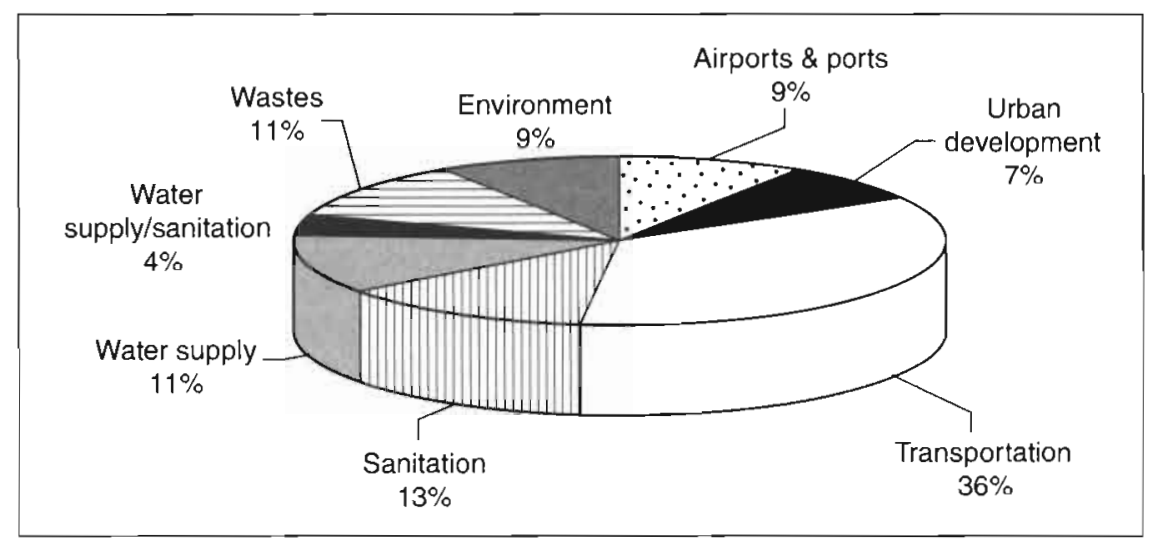

Source: Database of the authors.

\section{Foreign Experts' Perception of the Vietnamese Market}

Generally speaking, Vietnam today generates a lesser degree of enthusiasm than in the past, due to problems encountered by foreign investors and professionals, including consultants. The problems that development aid agencies have had to deal with in disbursing funds allocated for projects has had an impact on the evolution of mission opportunities offered to foreign consultants. Moreover, several engineering firms have found neighbouring countries, such as China and Thailand, to be more attractive in comparison.

Foreign consultancy firms do, however, perceive some positive points in their experience in Vietnam.

Beyond the dejection phase that often follows the initial - and perhaps excessive - enthusiasm, many foreign economic stakeholders tend to agree that the country has strong development perspectives, especially in the urban sector. Moreover, there is little doubt regarding Vietnamese people's aptitude for acquiring competences. In short, this is a country with a promising future.

In addition, many of the problems encountered are not specific to Vietnam, and are sometimes worse elsewhere, especially in countries where the administration is completely deficient.

Public project management generally pays a lot of attention to works carried out, even if it seems dubious that recommendations are actually 
being followed. Consultants are well aware that the country is currently going through a cultural gap between practices inherited from a planned economy and those associated with the current dominance of market economy. Despite this gap, Vietnamese project managers are assertive, pragmatic, and often know exactly what they do and do not want. If the gap can be bridged, this is an important condition for the implementation of profitable engineering practice.

Providing consulting services also implies having to face a strong demand for training young engineers. Vietnam has at its disposal a high quality skills pool with the capacity to take over from current senior executives eventually. Some consultancy firms such as Binnie Black and Veatch are firmly committed to partnerships with training institutions - in this case Ho Chi Minh City Polytechnic University. ${ }^{4}$

Interventions by foreign consultants are often carried out in close interaction with teams of Vietnamese experts. Almec and Sogreah, for instance, work with about thirty Vietnamese engineers (on the transport master plan for Ho Chi Minh City in the case of Almec and on ADB's water and sanitation project, also in Ho Chi Minh City, in the case of Sogreah). The American consultancy team Camp Dresser \& MacKee had to collaborate with fifty or sixty local consultants from Viwase on the detailed design of two sanitation projects in Ho Chi Minh City. Such collaborations have advantages and disadvantages, but ultimately, they allow foreign engineering experts to suggest their own professional practices and to establish themselves more firmly in Vietnam. Incidentally, foreign consultants have no compunction about recruiting the best elements among those despatched to their offices by Vietnamese engineering firms, in order either to use them in Vietnam or to send them to other regions - such as the Middle East - at a reasonable cost.

Although this might seem beyond the remit of our research, we should mention the attachment that many expatriates feel for this country - especially as many men are married to Vietnamese women - and which is not limited to the Viet Kieu. Vietnamese stakeholders themselves are clearly aware of this bond and tend to make subtle use of it. This essential element can explain the combativeness with which some consultants persist in working in Vietnam.

Having said this, do foreign consultants feel that they are playing an immediate role in methodological or conceptual innovation within urban projects? When asked about their individual experience, the overall answer is negative. The general opinion that it is difficult to "convey messages" combines with the feeling that authorities ultimately act as they please, 
based on partially technical rationales. Foreign experts sometimes hold opposing views in their conceptions: an example of this was the choice between lagooning, recommended by consultants mandated by a Belgian cooperation, and activated sludge, advocated by the Japanese, for cleaning up Lo Gom Canal in Ho Chi Minh City. Such debates obviously help authorities to define their own positions. However, beyond this, even the Japanese find it very hard to measure the impact of their interventions on the ways of thinking and working of decision-makers and their subordinates, and this despite the wealth of means provided by JICA (for example, master plan elaboration methods, SCADA software for transport demand planning, scheme for training Vietnamese consultants in Japan, etc.). Other foreign consultants are highly dubious about the idea that they might be transferring a so-called model within the framework of their missions.

Nevertheless, the fact that consultancy firms only have a rather hazy notion of the overall activity of foreign engineers in Vietnam is somehow symptomatic. They are no better equipped than their Vietnamese partners in having a global and dynamic view of the exchange process and transfer of know-how over a long period. In fact, they communicate very little amongst themselves; the consultation processes recently put in place mainly affect cooperation agencies. Calls for tenders for engineering services do not require any prior understanding of the conditions of intervention; the only important elements - other than the price bid — are the references of the prospective bidder and the individual CVs submitted. They do not require the bidder to be interested in what becomes of his own recommendations. Is Semaly aware that the study it carried out in Ho Chi Minh City in 1997-98 still provides inspiration to decision-makers regarding the development of public transport services? Good research often leaves a deeper legacy than consultants might think. Vietnamese decision-makers and foreign consultants have different time frames. Without being specialists of the Vietnamese decision-making system, we can hazard a guess that decision-makers might have no other option but to "store" recommendations and deal with them progressively, through a sort of careful distillation process required by the complexity of choices and balance of power between individuals and administrations, not to mention objective constraints such as financial and social costs.

\section{Vietnamese Consultancy Firms}

There are currently over 620 Vietnamese consultancy firms, all sectors included. The engineering sector, which numbers a total of over 20,000 
engineers, experts and technicians, has gradually become a numerically sizeable force as investment and construction projects have multiplied.

Vietnamese engineering and consultancy firms are currently proliferating. They can be divided into four categories: public engineering, universitybased research centres and research institutes, private consultancies and joint ventures (that is, mixed capital companies) resulting from foreign intervention.

\section{Public Engineering}

Public engineering companies dominate the market. They originate from the technical ministries or public enterprises, mostly from the Ministry of Construction and the Ministry of Transport and Communications, and generally have public enterprise status. They benefit from largely captive markets: in international projects, their participation is often imposed by public project management, which is more or less well received by foreign consultants. Some consider that such an advantageous position hinders the improvement of their professional capacities. Public engineering firms have, to say the least, very patchy skills. They can be excessively influenced by civil engineering and by a monosectoral culture. Public engineering firms are slowly improving their know-how concerning master plans and methods used for carrying out studies (for example, modelling, use of digital mapping, research methods). Historically, the country's de facto polarisation has resulted in the market being relatively divided, with some companies predominantly involved in the South (for example, Wase, Nagecco, Transport Development and Strategy Institute South) and others in the North (for example, Viwase, CDC, Hanoi's Transport Development and Strategy Institute), which obviously also implies a sectoral division (for example, energy, transport, water, etc.).

Public engineering companies are currently undergoing a transition phase characterised by a tendency towards progressive emancipation from a rigid administrative modus operandi. International donors are also exerting pressure on the authorities to stop public engineering from holding an undisputed position in the public markets. There are curbs to this tendency, especially regarding the threat to employment from the progressive corporatization of public engineering. Some structures employ a surplus workforce in relation with the value added produced.

\section{University-based Research Centres and Research Institutes}

University-based research centres originate from research laboratories and position themselves as professional expertise - generally in the upstream 
phases of engineering (research and consultancy) in order to develop their own functioning and, in the case of "private" universities at least, to improve the way their experts are treated. There are many of them but they have limited human resources. Some are nevertheless making a name for themselves in certain sectors (waste, environment). Research institutes (for example, Ho Chi Minh City and Hanoi's Urban Planning Institutes, Ho Chi Minh City Economic Research Institute and Hanoi Economics Institute) or associative private institutes (for example, the Institute for Urban Studies for global urban planning) also position themselves in the expertise market.

\section{Private Structures}

There are still few truly private consulting firms in the areas covered by our research - indeed, the legal distinction between public and private remains unclear. There are few qualified independent consultants working full-time and making a living from this work. Most of the experts hired as freelancers on development programmes and international projects are, in fact, part-time consultants with a permanent position in either a research institute, a university, or an administration agency. There are also many former government employees pursuing an independent career after retirement age (fifty-five for women and sixty for men).

Private structures are usually created at the initiative of private individuals, or more often of networks of individuals. They position themselves freely in the market for private projects, but public engineering firms often hire those with the strongest reputation as subcontractors for specialized work. Some such consultancy firms are starting to become international (for example, Van Xuan, Hadecon), though this mostly remains limited to Laos. They are usually managed by experts with a high level of technical skills and a solid network of contacts - especially within the administration. Their value added is not merely technical but also cultural: they must be able to prevent or smooth out differences between foreign consultants and project management.

\section{Joint Venture Companies}

At one point, joint ventures with State enterprises were a legal necessity for foreign companies seeking to establish themselves in Vietnam in the long term. The number of joint ventures in the field of urban network engineering ${ }^{5}$ remains limited, though not negligible. Firstly, few foreign consultants have reached a sufficient business volume in a single sector to consider a close partnership with a local company, as the latter is often mono-sectoral. As 
regulation became more flexible, they have tended to keep their margin for manoeuvre by favouring subcontracting or co-contracting contracts. As for Vietnamese consultancy firms, they hesitate to form partnerships with their foreign colleagues through fear that their best elements might get poached through the joint venture. The overall experience of joint ventures tends to show a distribution of roles whereby the subsidiary is confined to traditional civil engineering services, while the foreign shareholder takes charge of services requiring more elaborate know-how. Joint ventures have clearly not been truly innovative solutions. They even come across as a legacy from the past: their creation has led neither to the non-native partner being surpassed, nor to a real melting-pot of corporate cultures.

Vietnamese technical engineering remains fragmented and even splintered. Few connections exist beyond collaborations borne of technical or commercial necessity. Individualism predominates. One of the major stakes currently being played out is probably the ability of public organizations to keep an appropriate distance from project management. Most heads of Vietnamese consultancy firms are men of influence equipped with strong networks, and whose profile is ill-suited to the requirements of modern engineering. This leaves the young engineers, who are often discreet, yet key players in the successful implementation of international projects.

\section{The Vietnamese Look at Foreign Engineering Activities}

Foreign consultants are by and large seen by Vietnamese project management representatives as competent and professional, independently of problems encountered on the ground and of their national origin. From the Vietnamese perspective, there is a perfect convergence regarding the virtues expected from a high-level foreign consultant:

- ability to understand demand;

- ability to formulate clear-cut judgments and precise recommendations;

- knowledge of the practices and procedures of international organisations;

- experience acquired in other countries;

- specialisation, ability to address each issue in depth;

- development of tools for analysis (models) and rigorous approach, database construction and survey methodologies;

- knowledge of new technologies;

- fast and efficient work, rigorous adherence to the terms of reference, excellent communication abilities, very good document presentation. 
The criteria are set very high, but international engineers can also be the object of biting criticism. While recognizing their professional superiority, some Vietnamese stakeholders talk about difficult and sometimes conflicting collaborations. The expert is not required to solve a problem - the choice remains in the hands of project management - but to express an unambiguous opinion. Nuanced analysis can thus be badly received and interpreted as incompetence. At the other extreme, the arrogant and even contemptuous attitude of some foreign consultants betrays a serious lack of consideration and a poor knowledge of the local context. In this respect, culture and communication are an essential aspect of the relation between foreign consultants and their local partners.

Many high-ranking officials in the administration nevertheless realize that not all problems on the ground can be blamed on foreign engineers: the unavailability of civil servants, the deficiency of several Vietnamese consultancy firms, the inadequate abilities and responsibilities of the PMUs, ${ }^{6}$ who are meant to supervise consultants (for example, lack of understanding of the studies' terms of reference), or technical services' lack of independence from the political sphere.

Another fundamental problem is the lack of information regarding consultancy firms working in Vietnam and the skills they have to offer: besides the indications provided to project management by international organizations and experiences with various consultants, the community of engineering consultants and its operating practices are not well known. The Ministry of Construction would like some efforts to be made to fill these gaps.

In a context where urban issues are rapidly growing in complexity, Vietnam has high expectations from foreign consultancy firms in terms of transfer of know-how. The main task expected of them consists in guiding Vietnamese engineering firms in their appropriation of international professional practices: design and supervision of large-scale technical systems (for example, large purification units, high capacity landfills, underground railway and trams...), planning, management and maintenance planning, quality control, etc. Such transfers should be enacted through daily collaboration. In this respect, the Vietnamese feel that they are confronted with two major problems: the lack of enthusiasm shown by foreign consultancy firms for guiding the development of their local competitors, and the terms of the service contract as defined in the assistance contract. The Vietnamese sometimes express strong doubts regarding foreign engineering firms' actual intention of sharing their know-how.

Another endless source of conflict is the divergence in the conception of time between foreign consultants and their Vietnamese partners. Requirements 
imposed by financial institutions can be rigid and sometimes unrealistic in relation with the pace of decision-making in local administrations, which can put foreign consultancy firms in an untenable position.

Fair rates of payment for intellectual services and awareness of their financial value are still not part of dominant culture within Vietnamese administration. Wages paid to foreign consultants, which can be up to twenty times those of their Vietnamese counterparts, can often seem totally outlandish; moreover, the older generation of decision-makers are not always convinced of the interest of accumulating studies, considering that foreign experts come and go with the implicit aim of selling technology or projects (for example, underground railway, water refinery). From a Western point of view, one of the paradoxes of the Vietnamese context is the fact that technocrats obviously read studies with great interest, and probably make use of them in inter-administration rivalries.

Disagreements are considered normal. But it is the attitudes held on either side that can lead to deadlock. In this respect, project management seems to have more affinities with Asian experts, who are closer culturally, and with nationalities reputed for their flexible thinking (that is, Scandinavians).

Disagreements on recommendations often focus on two areas. Firstly, technological or technical aspects, where the options suggested can clash with regulations or existing administrative procedures (for example, drinking water), or be opposed by arguments regarding cultural issues (for example, public transport, public road works) or even political issues. Secondly, they focus on general planning decisions: foreign experts are more sensitive to issues such as preserving the ancient urban setting, space-saving and keeping expropriations to a minimum, whereas the Vietnamese aim first and foremost to address a clearly defined need, such as maintaining traffic flow by widening the roads. Foreign consultants are often accused of trying to impose at all costs an advanced technological solution (for example, waste treatment, water distribution) - which benefits corporations in their home countries - based on their previous experience in another country, regardless of whether they may be ill-adapted to the local context.

\section{The Case of Urban Transport}

International consultants in the field of transport in Vietnam are carrying out two types of intervention: one-off studies and strategic studies. The first deal with one specific infrastructure, such as urban road network, airport, bridge, renovation of intercity rail network, etc. They are essentially technicaleconomic studies. The link between infrastructure and urban transport is 
rather weak: even studies which take into account the transport system as a whole fail to have an overall perspective on what the objectives for this system should be at the date the infrastructure is put in operation, and on measures needed to put such a system in place.

The second type of interventions concern essentially strategic studies, which take into account the overall urban transport system and its future and recommend measures to be implemented in order to reach the given objectives.

It would be worth reviewing, at some stage, the recommendations suggested by consultants and looking into how they were taken in by political decision-makers. We will come back to this later.

\section{The Interventions}

More appropriate at this point is the presentation of the interventions according to their nature, the cities concerned and the nationality of consultants.

Hanoi and Ho Chi Minh City are the major recipients of the initiatives inventoried (thirty-eight) whereas medium-size cities only received three projects (in fact there were five: two more should be added, but which are not included in the current database). ${ }^{7}$ Aid in the two metropolises has so far prioritized urban transport, whereas efforts deployed in provincial areas mostly targeted the road or motorway network and large-scale infrastructure such as tunnels and bridges, in order to improve communication with and between medium-size cities. Projects for the Hanoi-Haiphong and the Haiphong-Kunming corridors are two such examples.

Interventions can be grouped according to type in the two main cities (Table 8.1).

TABLE 8.1

Interventions of Transport Consultancy Firms, Hanoi and Ho Chi Minh City

\begin{tabular}{lccr}
\hline \multicolumn{1}{c}{ Type of intervention } & Hanoi & HCMC & Total \\
\hline Public transport & 11 & 6 & 17 \\
Specific studies (pollution, etc.) & 4 & 9 & 13 \\
Master plan or equivalent & 2 & 3 & 5 \\
Studies/ infrastructure projects & 0 & 1 & 1 \\
Others & 0 & 1 & 1 \\
\hline Total & 17 & 20 & 37 \\
\hline
\end{tabular}

Source: Database of the authors. 
The dynamism of infrastructure projects wins the day in Ho Chi Minh City, with the biggest names in traditional Anglo-Saxon engineering, such as Arup, Maunsell, and Louis Berger International. In contrast, there are more studies on public transport in Hanoi, even if "projects for projects" add renewed vigour to Ho Chi Minh City - there is also talk of intervention by Russian consultants.

Hanoi and Ho Chi Minh City tally the same number of interventions by foreign consultants, that is, seventeen each (Table 8.2). French and Japanese missions predominate (twenty-one out of a total thirty-four), but the French figures are amplified by the presence of two agencies that are not consultancy firms, Transdev and RATP International, with one intervention each, not to mention the CETE/CERTU expertises mobilized in 2003 in Hanoi. Moreover, one of the French projects concerns lighting more than it does transport. These factors considerably reduce the actual proportion of French transport engineering, which can be summed up to two interventions by Systra and Semaly (public transport), the mission entrusted to the small Parisian consultancy firm Explicit ${ }^{8}$ by ADEME, and a joint engineering intervention by Thales and Coyne and Bellier for the renovation of Hanoi's Long Bien Bridge.

Although not specifically urban, a study by BCEOM on transport in the central region of Vietnam could make up for this weak French presence, but, as is the case for the areas of water and waste, the assessment shows that French activity remains thin on the ground.

TABLE 8.2

Interventions in Transport Engineering per Consultants' Country of Origin, 2000-04

\begin{tabular}{lccr}
\hline \multicolumn{1}{c}{ Country } & Hanoi & HCMC & Total \\
\hline Japan & 5 & 6 & 11 \\
France & 5 & 5 & 10 \\
United States & 1 & 2 & 3 \\
United Kingdom & 1 & 2 & 3 \\
Sweden & 3 & 0 & 3 \\
Germany & 2 & 0 & 2 \\
Australia & 0 & 2 & 2 \\
\hline Total & 17 & 17 & 34 \\
\hline
\end{tabular}

Source: Database of the authors. 
In contrast, Japanese interventions are characterized by the balance between general planning services, feasibility studies, detailed design and works supervision. They testify once again to the interest of the Japanese for urban transport in East Asia (Baye and Cusset 1990).

Japan has initiated three master plans out of the five large-scale general planning studies identified in the two cities over this period:

- master plan for transport in Ho Chi Minh City for 2010 (2002-04) - Almec Corporation;

- improvement of transport in Hanoi (1999-2002) - Arup Group (Hong Kong);

- master plan for Hanoi (1997) - Yachiyo Engineering Co and Katahira \& Engineers International;

- study for the development of transport in Ho Chi Minh City for 2020 (1996-98) - MVA Consultancy, Maunsell and Transport Research Laboratory;

- general transport study in Hanoi based on the 1997 master plan (1998) - Pacific Consultants International.

The budgets at stake, as well as the social and economic implications (for example, cost of public transport, relocation of populations) are such that Vietnamese authorities are proceeding with caution in the area of transport. Some foreign consultants assume that relevant authorities are accumulating studies in this field in order better to compare their options.

\section{Studies Conducted on Transport Systems}

At least fifteen studies on urban transport - of which six were major studies - were carried out in the two Vietnamese metropolises from 1990 to 2002." Other than the study conducted within the framework of the project "Vietnam Urban Transport Improvement", ${ }^{10}$ no actual work was executed immediately after completion of any of these studies, due to a lack of funding. However, some of their major suggestions were in one way or another included in the urban transport policies implemented in Hanoi and Ho Chi Minh City. These studies are in fact enabling a long process of impregnation of Vietnamese attitudes.

Few of the strategic options and policies suggested by foreign consultants are new in themselves. They often consist in improving previous options, sometimes reinforcing them with technical analyses or by updating the collected data. The real issues seem to have been the inability to implement technically efficient urban transport policies and the lack of financial means. 


\section{Transfer of Know-how and Training Actions}

The interventions of foreign consultants in the field of transport are generating an increasing transfer of know-how in different areas, whether it occurs during the course of in-depth studies or through the presence of a permanent team. We will mention a few significant examples.

In 1997, MVA in association with Maunsell carried out the first in-depth study of Ho Chi Minh City's transport system while conducting training and transfer of technology activities. Throughout the study, the Vietnamese team, which was composed of individuals from different departments (Transport and Public Works, Ho Chi Minh City Road Police, Ministry of Transport's Transport Development Strategy Institute), worked alongside teams of foreign consultants. In addition, a series of research trips to several Asian cities was organized. The Vietnamese team was able to observe the way in which other Asian cities deal with transport issues and to anticipate the consequences of decisions taken in Ho Chi Minh City.

MVA experts sent by the parent company organised seminars in association with the Vietnamese team. Some of the managers selected by TPWS were also trained by MVA and TRL (Transport Research Laboratory) in the United Kingdom. Two TPWS technicians attended a formal course at the University of Southampton. In addition, TDSI and TPWS staffs were trained to use the transport planning model. It would also be essential for TPWS staff to continue improving these skills and using these tools permanently. However, organisational inadequacy within Ho Chi Minh City administration has resulted in the inefficient use of the software and technical equipment provided by MVA." The same problem occurred when foreign experts installed public transport networks management software which relied on data collection in real time.

More recently, the HOUTRANS ${ }^{12}$ team in Ho Chi Minh City, coordinated by the Japanese consultant ALMEC, has brought together foreign experts of different nationalities to conduct training and transfer of technology actions.

\section{The British Consultant ARUP (Hong Kong Office)}

ARUP played a major role in improving the current traffic situation in Ho Chi Minh City and in Hanoi within the framework of the project "Vietnam Urban Transport Improvement" (2000-04). They set up quite efficient measures which did not necessarily require vast expenses. An example of this was the channelization of streets in the central districts, whereby several two-way streets were turned into one-way streets. This brought about an improvement 
in traffic circulation, especially at Bay Hien, one of the city's most important intersections. The success of these operations spurred the Transport and Public Works Service to extend the one-way system to other streets in the capital, such as Nguyen Kiem and part of Xo Viet Nghe Tinh. ${ }^{13}$

Before ARUP's intervention, there were only a few one-way streets in Ho Chi Minh City. The consultant initially encountered strong opposition from shop owners with frontage on the streets as well as private transport users concerned about the fact that a one-way system would make their route longer. Residents finally came to accept the one-way system as they realized that this was counterbalanced by a better flow of traffic and improved road safety.

\section{Restructuring and Reinvigorating the Bus Network in Hanoi and Ho Chi Minh City}

Since the beginning of the 1990s, international consultants have made several studies and proposals to revitalise the public transport system in Hanoi and Ho Chi Minh City, which had continued to collapse in the years following Doi Moi.

In Hanoi, the main measures concern the creation of pilot lines and segregated bus routes, the implementation of a better-adapted fare structure with attractive season tickets, and improvement of the service. A similar policy was later adopted in Ho Chi Minh City with similarly encouraging results.

\section{SEMALY (France) and ALMEC (Japan)}

SEMALY was the first foreign consultant to recommend segregated corridors in Vietnam: one corridor for the bus and for the tram on Tran Hung Dao Avenue. Urban transport policy makers in Ho Chi Minh City agreed to this proposal, but the amount of investment needed exceeded the city's means at the time, so the People's Committee did not follow up this recommendation. The idea was more recently suggested by ALMEC as part of its Policy Test Project from August to October 2003, which is an integral part of the transport master plan for Ho Chi Minh City (HOUTRANS) in 2004 and will be continued by Vietnamese authorities. The objectives of HOUTRANS are manifold. Firstly, their aim is to determine a long-term strategy to improve the mobility of inhabitants in this urban area with the development of a master plan for 2010 and 2020; secondly, to define a plan of action for 2005 based on the master plan and to carry out feasibility studies for priority projects.

During the trial period, a number of traffic management measures were implemented by Vietnamese authorities on Tran Hung Dao Avenue to 
FIGURE 8.6

\section{Bus Lanes in Ho Chi Minh City and in Hanoi}
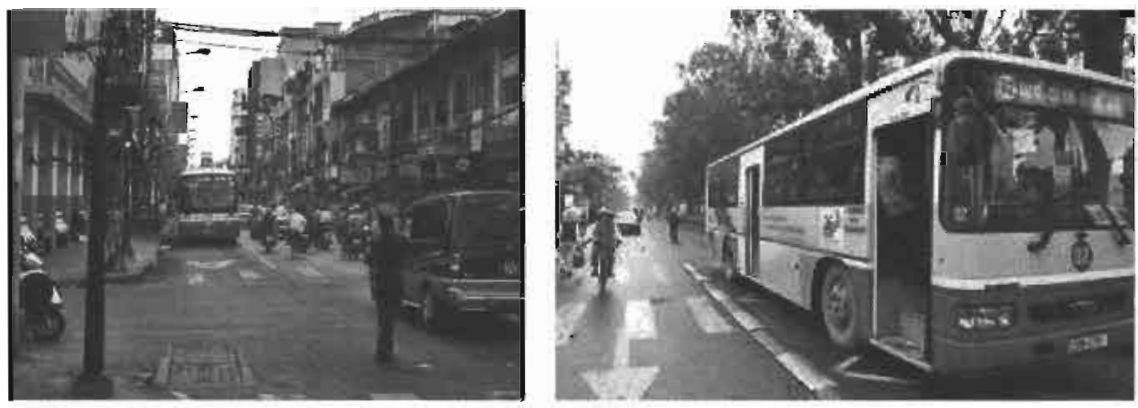

Photos: HOUTRANS Newsletter no. 3 and Vietnam News.

improve service efficiency on line 1: no parking on the road, cyclists to turn left in two stages, centre point marking and development of a priority bus lane. ${ }^{14}$ ALMEC's survey of the avenue's frontage residents after the trial period showed a high level of public acceptance. In parallel with traffic management measures, new air conditioned, large capacity buses 80 seats - were put in service to replace existing buses. Other performance indicators improved, especially with longer hours of service, from 4.30 a.m. to 9.30 p.m. Bus users noticed an improvement in the supply and quality of the bus transport service. Over 70 per cent of interviewed passengers approved of its new service period, as well as its punctuality, comfort on board and safety. Average daily patronage has noticeably increased, from 8,300 passengers in July 2003 - before the project was implemented - to 15,700 passengers in October 2003. ${ }^{15}$

In line with the recommendations of Dorsch Consult, we should mention the Hanoi Urban Transport Development Project initiated by Hanoi People's Committee. One of the important parts of this US\$125 million project, which was mostly funded by the World Bank, is the establishment of bus routes with dedicated right-of-way. ${ }^{16}$ The authorities of Hanoi have recently inaugurated a 4.2 kilometres designated bus lane from $\mathrm{Nga} \mathrm{Tu}$ So to $\mathrm{Ha}$ Dong, used by ten bus lines either in part or throughout.

\section{Restrictions on Private Motorized Transport}

Several consultants, in their diagnosis of the transport system, estimate that the growing motorization of city-dwellers cannot continue at the current rate, that its social and private costs are increasing, and that it is making 
the shift to public transport more difficult, especially as public transport is still far from efficient.

The Japanese consultant Yachiyo Engineering who, from 1995 to 1997, was responsible for developing a master plan for urban transport in Hanoi, and for carrying out feasibility studies for priority projects, recommended restrictions on the use of private cars, even though there were only six cars for 1,000 inhabitants in 1995. A system such as the Area Licensing System - the Singaporean urban toll - was suggested for the Old Quarter and the French Quarter. According to Yachiyo Engineering, if authorities want to avoid congestion problems in the central districts, construction of car parks should also be restricted.

In 1996, MVA was the first foreign consultant in Ho Chi Minh City to raise the issue of restricting the use of motorised two-wheeled transport in some of the city's central areas. Although the People's Committee did not take the proposals into consideration at the time, it has started to impose restrictions on the circulation motorised of two-wheeled transport in October 2002.

These measures were not implemented immediately after the studies were completed. Consultants' recommendations sometimes undergo a long brewing period. Introducing measures for citizens who demand the right to circulate more easily to earn a living is no easy task. Despite an increase in congestion and the multiplication of traffic accidents, restrictive measures still encounter opposition among the population. The motorcycle was, until recently, a status symbol, but has become a convenient mode of transport to earn one's living. Authorities initially hesitated to take unpopular decisions. However, after the spectacular growth of the fleet of motorised vehicles, and in particular motorcycles in 2002, the Ministry of Transport, followed by the Transport and Public Works departments in both metropolises, announced restrictive measures through the press, although they actually only came into force in 2003.

\section{Which Mass Public Transport System?}

Consultants have different approaches in this area. Dorsch Consult (Germany, Egis Group), which was called upon for the development of urban rail transport in Hanoi, strongly recommended the development of BRT (Bus Rapid Transit) or public transport by bus in designated sites, whereas the Vietnamese, from inhabitants to authorities, will for the most part only consider heavy underground rail for Hanoi and Ho Chi Minh City. According to Dorsch Consult, rather than investing in a heavy rail line 
carrying 108,500 passengers a day for a cost of about US\$298 million, the same amount can be invested in the development of seven or eight bus lines in designated sites distributed over the entire city.

Once the population has been encouraged to use the bus more frequently and the network sees an increase in patronage, it should be much easier to maintain the viability of a mass transport system based on rail with a solid level of certainty - which is vital considering the intensive capital investment required for such a system.

Should it be introduced directly, without first going through an intermediate stage, urban mass rail transport runs the risk of not attaining a sufficient rate of patronage and becoming a heavy financial burden for the Vietnamese authorities as well as potential investors. High financial debt could result from the costs of intensive line haul and maintenance of the rail systems, should these be inadequately covered by revenue from passenger fares.

The abovementioned consultant, Yachiyo, recommends the construction of a heavy underground rail on condition that the project be economically and financially viable. In this sense, its views are similar to Dorsch Consult, who carried out a study on urban rail for Hanoi. Systra, who was responsible for a feasibility study for a tram in Hanoi from the end of 2004, also thinks that heavy underground rail is an option to be considered in the long term, whereas light underground rail would constitute a first stage in the establishment of urban track-guided transport.

However, development programmes for mass public transport cannot in themselves change inhabitants' preference for private transport, especially as its cost is extremely low, considering that public road users do not pay the real social cost generate by their mobility.

In Hanoi, the main measures implemented concern the creation of pilot lines and of segregated corridors for buses, the implementation of better adapted fares with attractive season tickets and the improvement of the quality of service. Decentralized cooperation between the Île-de-France Region (IDF) and Hanoi People's Committee has largely contributed to the renewal of public transport in the city. The IDF Region has undertaken, together with Hanoi People's Committee and Brussels-Capital Region, to improve the functioning of the bus network by requesting co-funding from the European Commission on three pilot lines (Asiatrans project). Within this project, the IDF Region has mobilized the expertise of RATP professionals for renovating and providing equipment to one of the bus fleet's maintenance depot, and for training bus drivers and bus controllers. It also co-financed research and development for the first bus correspondence point from Hanoi to Cau Giay. 
In anticipation of the need for more capacious modes of transport, the IDF Region played a driving role in the emergence of the East-West tram project. It commissioned a pre-feasibility study in 2001 at the People's Committee's request. Through the Urban Workshop Institute, its cooperation agency in Hanoi, the IDF Region undertook surveys of bus lines patronage and traffic, used as references for the feasibility study carried out by Systra in 2004 to estimate the tram patronage for 2010 and 2020 .

The first bus pilot line, successfully launched at the initiative of a German consultant (see below), benefited from vast support from the Hanoi People's Committee, from the cooperation of the Tram Company's managing director, and assistance from several colleagues.

After the initial success of this pilot line, the consultant was called upon to improve the quality of service on line 22 operated by the $10 / 10$ Bus Company. He is currently continuing his assistance and consulting work with MOCPT Hanoi within the framework of the Asiatrans project initiated by the IDF Region and Hanoi People's Committee (see below).

\section{An Independent German Consultant in Hanoi}

A German expert, sent in 1999 for a period of several years to work in an operational unit ${ }^{17}$ of the TPWS (Transport and Public Works Service) in charge of public transport, had an essential and decisive role in the renovation of Hanoi's public transport network.

From the moment of his arrival, he suggested to three companies that they relaunch public transport. The Tram Company, with its young managing director, was the only ore to take up the challenge. A pilot operation increasing the hours of service was conducted on line 32. The other companies considered that extending the service period until 9 p.m. was a waste, that the bus would be carrying wind rather than people, and that they could not assume the financial consequences.

"I don't think there is any point in carrying out a radical reform. It is better to start out by making good use of the available rolling stock. Rather than making new investments, the bus frequency should be increased," recommended this expert. He thus took the "spectacular" initiative of conducting a trial run on line 32 with only twelve old buses running every ten minutes, hours of service from 5 a.m. to 9 p.m. and attractive fares. On this pilot line, a stop in front of a university replaced a secondary stop. Students highly appreciated this change and bought 60 per cent of the 4,000 monthly passes. Previously, only 500 were sold.

A representative from MOCPT made the following significant statement in an interview carried out for this research: "... He gave us the impetus 
to relaunch public transport. He is responsible for putting public transport by bus on the right track. He took it upon himself to mobilize support from NGOs and from the German government to organize a series of conferences on public transport aiming to raise awareness among transport specialists and city managers regarding the need to relaunch public transport by bus. He also played a very important role in securing the Asiatrans project. Such a tangible contribution can be translated into figures, but his brain power, his expertise and the enthusiasm he has brought to Hanoi are priceless. We have decided to invite him to continue working as a consultant for Hanoi until the end of this project." 18

\section{Recommendations by Foreign Experts in Urban Public Transport Policies}

Interviews with Vietnamese policy makers in urban transport do not seem to indicate that the transport policy measures implemented in the two Vietnamese metropolises have any direct link with expert report recommendations. However, public speeches and press interviews given by authorities in charge of transport do point out that foreign expertise is indirectly or implicitly taken into account in urban transport policies. In fact, the straightening out of the bus network in Hanoi and Ho Chi Minh City, as well as actions carried out to control two-wheeled transport since the beginning of the $2000 \mathrm{~s}$, are striking illustrations of the change in attitude, triggered by several years of successive interventions by foreign consultants, of Vietnamese authorities at local as well as national level in relation to transport policies.

The case of public transport with dedicated right-of-way in Ho Chi Minh City is a good example of this change in attitude. Initially, financial constraints gave decision-makers no other choice but to "store" recommendations. Later on, with funding from JCA, they were able to approve the implementation of the consultant's idea.

Although policy makers themselves probably do not have time to read expert reports, officials from the Transport and Public Works Service (TPWS) in both cities, who advise policymakers on policy development, pay a lot of attention to what consultants have to say. This is the case of the current managing director of TPWS in Ho Chi Minh City. From August to November 2004, for instance, he was very firm regarding the implementation of restrictive measures. In order to convince the People's Council regarding the more revolutionary measures such as the urban toll, he quoted the conclusions of the Japanese experts: "There will not be any space left to circulate in Ho Chi Minh City if the fleet of motorcycles exceeds 
2.5 million and if the number of cars does not cease to grow."19 However, in order to mitigate the unpopularity of the measures, he recommended an opinion survey among 10,000 persons as an essential prerequisite.

In fact, the Ministry of Transport and the consultancy firms under its aegis, such as TDSI North and TDSI South, as well as most heads of technical services within both municipalities, all publicly agree on restrictions on motorcycles and private cars. They share the idea that it would not be fair to restrict motorized two-wheeled transport while letting private cars circulate freely. However, the People's Council in both municipalities, and especially in Ho Chi Minh City, ${ }^{20}$ do not accept restrictive measures on motorcycles. According to them, motorcycles are an essential means of transport which enables the majority of the population to earn a living. As for restrictions on cars, the People's Council has to follow government directives. So what is the government opinion on the matter?

In his opening speech at the opening of a car factory in 2003, the vice-prime minister saw as unacceptable the fact that a country of nearly 100 million inhabitants did not have a car industry: "The development of this industry will enable the development of the mechanical industry."21 Paradoxically, towards the end of 2002, he spoke out in favour of a number of measures, including the restriction of motorized two-wheeled transport, to deal with the rapid increase in congestion and traffic accidents.

In short, foreign expertise has clearly been taken into account, at least in part, in urban transport policies. It is regrettable that there should not be a convergence in attitudes regarding what the urban transport system should be in the two big cities.

International and Vietnamese experts have always spoken of measures to be taken - including tax incentives - in order to discourage the excessive use of individual modes of transport. Vietnamese decision-makers have reacted to the critical situations of urban transport in the big Vietnamese cities; however, their reaction has not been translated into a favourable transformation of the system. Most urban transport officials are convinced that the use of individual modes of transport needs to be restricted. Yet the real decision-makers do not dare make unpopular decisions. They are often caught between the development of public transport and that of the motorcycle and car industries. An enlightened and proactive transport policy is essential to provoke a change of attitude among inhabitants, at least in favour of public modes of transport.

A sustainable urban transport system in Ho Chi Minh City, Hanoi and other big Vietnamese cities relies on clear orientations and firm commitments from both the government and municipal authorities. 


\section{Conclusion}

One thing is certain: in Vietnam, the concept of the transfer of models through international consultants is not relevant:

The role of foreign consultants remains limited, despite the virtues attributed to them locally. Their presence is largely dependent on rules imposed by financial backers, and is sometimes tolerated rather than really called for by local stakeholders. From the Vietnamese perspective, their role consists more in suggesting clear and substantiated options than in providing an adequate solution. Considering the difficulty of obtaining data, and the difference in time frame between experts and public decision-making systems, consultants risk finding their experience deeply frustrating, especially if they set out with the idea that they will generate the implementation of a specific project.

The expectations of foreign consultants and of the Vietnamese do not always coincide - far from it. Solid foundations are needed to hold one's ground in a dynamic market, which demands high levels of skill, time and patience. International consultant's prior knowledge of Vietnam is obviously too patchy for them to avoid disappointment and wrong moves, whereas the Vietnamese lack sufficient understanding of the rationalities of the engineering sector, as well as a truly shared capitalization of the results of the numerous missions on the ground.

Considering the high stakes of urbanization in Vietnam, the need for expertise and the country's assets, engineering - as well as the deep cultural questioning it provokes - should be the subject of bolder initiatives from public stakeholders in the field of training cooperation. Aid to capitalize on experiences and institutional support for project management would also be welcome.

What teachings from the approach developed in Vietnam could be used in other countries?

Within the framework of PRUD (Urban Research Programme for Development), our team was also able to carry out research - albeit not as in-depth - about Cambodia. Vietnam and Cambodia are at different stages in their relationship with foreign engineering firms associated to urban projects. Vietnam formulates strong demands and truly seeks methods for the transfer of know-how and strengthening of its local engineering force. Progression is not easy but the route is laid out. Cambodia is still in a real state of dependency, due almost entirely to the volume and modalities of aid. NGOs played a considerable role in the international support for Cambodia's recovery at the beginning of the 1990s. Several of 
them are currently positioned in the field of urban expertise through social priority projects. For the past decade, consultancy firms have progressively imposed a significant presence. The numerical preponderance of Japanese and French consultants over the period from 1990 to 2004 corresponds to these countries' level of bilateral aid, which was vastly superior to that of other countries. Local Cambodian consultancy firms are embryonic and there is no structured local engineering sector as in Vietnam, Thailand or the Philippines, nor any consultant's associations. Mixed groupings of local and foreign consultants are created on very flexible terms, usually due to the requirement to be associated with a local partner. Such consortiums often bring together one or two Cambodian experts recognised for their skills and one or more juniors responsible for çarrying out surveys, for instance. The role of the local partner can be limited to facilitating relations with public authorities and to lobbying.

The history of Cambodian urban expertise since 1993 is probably only just entering a second phase - one of resurgence - following the omnipresence of foreign consultants. The emergence of a third phase in five to ten years, with a fully formed local engineering sector, will probably remain marked by foreign professional influence more than elsewhere. Nevertheless, the same approach modalities of engineering seem to be operational in both cases, and open a field of observation and analysis for other countries and other sectors (for example, energy, port and airport infrastructure, development).

Basic investigations could be conducted in Cambodia as well as in Laos, and should be at least as comprehensive as those carried out by our team in Vietnam. From a regional perspective, an initiative including these three countries could be carried out, based on the PRUD's assets and experience and on the research network set up through this programme as well as on the active cooperation of development aid agencies. China, or at least its major metropolises, would also be a relevant subject for this type of study, even though its engineering force is at a different stage in its evolution - in fact, it would be appropriate to observe the difference in situation between the various provinces studied. Other countries currently neglected by French research programmes could also be studied: the Philippines, Indonesia, Thailand and Malaysia.

Urban dynamics at work in the Asia Pacific region show strong similarities, especially regarding infrastructure and environmental projects (Baye 1997). Beyond national idiosyncrasies, in order to be useful for cooperation strategies, analysis of engineering could be based on an approach capable of being replicated in different contexts. As for other regions, including South Asia, Africa, Latin America, the Middle East and Central Asia, it is important to 
remain cautious as to the relevance of our conclusions for regions that are very different culturally, and whose implementation mechanisms are not necessarily comparable. Nevertheless, it is likely that the issue of engineering will turn out to be just as relevant to urban research and cooperation there as in Southeast Asia.

Beyond national idiosyncrasies, in order to be useful for cooperation strategies, analysis of engineering could be based on an approach capable of being replicated in different contexts.

\section{Notes}

This chapter is based on the results of research conducted by Eric Baye, Économie et Humanisme (Economics and Humanism) as coordinator, Jean-Michel Cusset (Transport Economics Research Centre), Ton Nu Quynh Tran (CEFURD, Ho Chi Minh City), Nguyen Thien Phu (doctoral student at University Lyon 2) and Laurent Pandolf, with the active participation of Nguyen Ngoc Hien (IMV - Cooperation Centre for Urban Development, Hanoi).

1 For example, to simplify matters: development of incineration rather than landfills, priority to overhead or underground urban transport and on-ground public transport with dedicated lanes over traditional on-ground public transport, centralised waste treatment systems rather than small decentralized treatment units, etc.

2 Respectively Japan International Cooperation Agency and Japan Bank for International Cooperation.

3 Finnish, Danish and Australian cooperation agencies.

4 Through funding of Ph.D.s in the United States and subcontracting work.

5 For example, Apeco (PCI, Japan), Vietconsult (Nippon Koei, Japan), Hyder Consulting Vietnam (Hyder Group, United Kingdom).

6 Project Management Units (PMU) are responsible for representing project management on international projects. They are the direct discussion partners of the foreign consultants mobilized on such projects.

7 Interventions by Finnroad (Finland) in Haiphong: feasability study for the construction of RAO II Bridge (since 2000, funding' from the Finnish Foreign Affairs Ministry), detailed design and supervision of works for the construction of Binh Bridge (JBIC funding, mission carried out from 2000 to 2004 with the Japanese company Chodai Co Ltd and the Finnish company Kortes).

8 Supported by the Transport Economics Research Centre.

9 The Ho Chi Minh City Transport Study, by MVA, "Feasability Study for a Public Transport Line with Dedicated Right-of-Way from Benh Thanh to Binh Tay" by SEMALY, "The Master Plan of Urban Transport for Hanoi City in Vietnam", "Hanoi Urban Railway Feasibility Study" by Dorsch Consult and the most recent study, "HCMC Urban Transport Master Plan and Feasibility Study" (HOUTRANS). 
10 With ARUP Hong Kong as consultant and funding from the World Bank.

11 Interview with $\mathrm{Vu}$ Kien Thiet, Deputy Director, PMU of the Investment in Urban Transport and Le Qua, First Permanent Deputy Director, PMU (Project Management Unit of East-West Highway) of Ho Chi Minh City.

12 "HCMC Urban Transport Master Plan and Feasibility Study" (HOUTRANS). The research team, led by JICA experts, is based with TDSI South (Transport Development Strategy Institute in the South). The Japanese consultant ALMEC, that has been active in Asia for several years, is responsible for the overall project.

13 Interview with Vu Kien Thiet, Deputy Director, PMU of the Investment in Urban Transport.

14 Interview with ALMEC Managing Director Shizuo Iwata broadcast on Ho Chi Minh City television on 12 September 2003.

is HOUTRANS Newsletter no. 3.

16 Hanoi Urban Transport Project. Concept note for proposed GEF operation, 25 pp., <www.gefweb.org>.

17 MOCPT Hanoi (Management and Operation Centre for Public Transport).

18 Quoted by Tuoi Tre (Youth), Sunday, 8 December 2002.

19 Daily newspaper Tuoi Tre (Youth): "When Should Motorised Two-wheeled Vehicles be Restricted?", 5 August 2004.

20 During the $11^{\text {th }}$ Session of the People's Council on 21 June 2004, the council rejected a proposal from the Transport and Public Works Service suggesting that Ho Chi Minh City restrict its motorcycle fleet to 2.6 million and its private cars to 145,000 in 2005 .

21 According to Vietnam Economic Times, 20 June 2003.

\section{References}

\section{Books and Articles on Experts, Consultants and Their Markets}

Baye, Eric and Jean-Michel Cusset. Stratégie et marché des consultants aux Philippines et en Indonésie: le cas des transports urbains. Ministère de l'Équipement et des transports, 1990.

- "Les consultants dans le secteur des transports urbains en Asie du Sud-Est: cas des Philippines et de l'Indonésie". In Mobilité et transports dans les villes en développement. Transferts de modèles et échanges économiques Nord-Sud. Paris: L'Harmattan, 1992.

Baye, Eric and Dominique Lorrain. Le développement des infrastructures dans la zone Asie-Pacifique: mythes et réalités. 2001 plus..., no. 39 [publication of Ministry of Equipment and Transportation (DRAST/CPVS), July 1996].

Baye, Eric and Gérard Debizet. Des nouvelles problématiques urbaines à l'innovation de l'expertise transport: mise en parallèle et convergence avec trois pays européens: France, Allemagne, Royaume-Uni. Recherche conduite dans le cadre du Predit, Ministère de l'équipement et des transports, 2001. 
Dick, Howard W. and Peter Rimmer. "Urban Public Transport in Southeast Asia: A Case Study of Technological Imperialism?" International Journal of Transport Economics (June 1988): 177-96.

Godard, Xavier and Jean-Michel Cusset avec la collaboration de Matthias Schmitt. Les termes d'une politique de transport urbain au Viêt-nam dans le contexte de la transition. Colloque AUPELF/UREF sur Développement et transition vers l'économie de marché, Hanoi, 5-6 December 1996.

Molt, Walter. "The Transformation of Public Transport in Hanoi". In IMV, Regards croisés sur Hanoi. Transition, spécificité urbaine et choix de développement. Actes de séminaire, 2002, pp. 131-38.

Rimmer, Peter James. "The Internationalization of Engineering Consultancies: Problem of Breaking into the Club". Environment and Planning, A, vol. 20 (1988): 761-88.

\section{Consultancy Reports}

CONTRANS, MARITERM. Urban Transport in Hanoi. Diagnostic Study 1993. Hanoi: SIDA, Hanoi People's Committee, 1993, 122 pp.

CONTRANS. Urban Transport in Hanoi. Diagnostic Study 1993. Executive summary, 1994.

- Vietnam Urban Transport Assistance Project. Hanoi: SIDA, 1995.

Ho Chi Minh City Transport Study. Draft final report. Viêt-nam DFID-MVA, 1998.

HOUTRANS, ALMEC Corporation. Study on Urban Transport Master Plan and Feasibility Study in HCM Metropolitan Area. Draft final report, 2004.

JBIC. Urban Public Transportation in Vietnam. Improving Regulatory Framework. Research Paper no. 4, 1999.

RATP International. "Le défi du transport collectif de Hô Chi Minh Ville". Le Projet "Saigon Métro", unpublished, 1999.

SEMALY, TDSI South. "Etude de faisabilité d'une ligne de TCSP de Ben Thanh à Binh Tay". Rapport économique, unpublished. 1998.

SYSTRA. Etude de faisabilité d'une ligne-pilote de tramway à Hanoi, 2004.

Technical University Dresden. "Pre-feasibility Study: Construction and Reinforcement of the Rail Transit Systems in HCMC by the year 2020". Summary, unpublished, 1997.

TEWETT-TDSI South. "Résumé de l'étude de faisabilité pour le projet de 2 lignes de métro prioritaires de Hô Chi Minh Ville", unpublished, 2003, $10 \mathrm{pp}$.

Thalès-SARECO. Etude des transports intégrés et durables à Hanoi. Étude initiée par la coopération entre la Région Île de France et le Comité populaire de Hanoi, financement du Fonds français pour l'environnement mondial, 2004.

World Bank. Ho Chi Minh City Urban Transport Improvement Project. Project Appraisal Document. Washington D.C., 1998.

YACHIYO-JICA. The Master Plan of Urban Transport for Hanoi City in Vietnam. Tokyo, 1997. 


\section{Conferences and Seminars (Conference Proceedings)}

Actes de colloque (en vietnamien). Les deux-roues à moteur: Responsable de la congestion et des accidents routiers - État des lieux et Solutions. Organisé à Hô Chi Minh Ville le 14 November 2002 par le Journal Le Travailleur.

Actes du Colloque International. "Les transports du XXI" siècle". Hô Chi Minh Ville, 20-21 April 2000.

Colloque franco-vietnamien. "Transports urbains". Organisé par UBIFRANCE et la mission économique de l'ambassade de France. Hô Chi Minh Ville, 24 October 2003.

"Conference on Solutions for Public Transportation in Hanoi Capital". Organisée par Hanoi Foreign Affairs Department, Transport \& Urban Public Works Service and Siemens AG. Hanoi, 13 December 2000.

"Les expériences du Japon de la création d'un fonds de développement du réseau routier et les mesures de la sécurité routière". TDSI South/JICA, 28 February 2003.

HCMC Department of Planning and Investment. Urban Public Transport in HCMC. Ho Chi Minh City, 14 September 2001.

"Seminar on Mass Transit Development Strategy in Ho Chi Minh City". Organisé par TDSI-JTCA. Ho Chi Minh City, 16 October 2000.

"The Seminar on Urban and Public Transport Development in Hanoi City". Organized by JTCA. Hanoi, 25 February 2003.

"Transports et environnement à Hô Chi Minh Ville: du diagnostic à l'action". TPWS-DOSTE. Hô Chi Minh Ville, 14-15 May 2002. 